\title{
Iowa Congressional Leaders, 1921-1932
}

Philip A. Grant, Jr.

ON APRIL 11, 1921 the First Session of the Sixty-seventh Congress was called to order. Taking their oaths of office on that day were ten congressmen from Iowa. Without exception these ten individuals were to play pivotal roles in the nation's affairs during the administrations of Warren G. Harding, Calvin Coolidge, and Herbert $\mathrm{C}$. Hoover. In addition to wielding considerable influence in the halls of Congress, several of these gentlemen were destined to occupy positions of high responsibility in the executive and judicial branches of the federal government.

Among the Iowans participating in the opening ceremonies on April 11 were Representatives Harry E. Hull of Williamsburg, Lester J. Dickinson of Algona, William F. Kopp of Mount Pleasant, and Cassius C. Dowell of Des Moines. Hull, Dickinson, Kopp, and Dowell were each to serve on important House committees.

Hull in April 1921 was be-

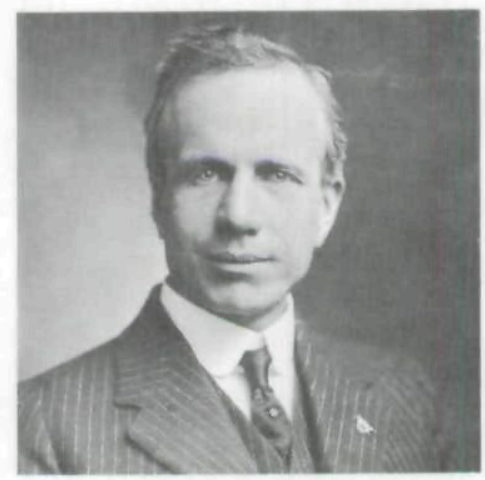

Harry E. Hull* ginning his fourth term in Congress. ${ }^{1} \mathrm{~A}$ senior member of the

'Lawrence F. Kennedy (comp.), Biographical Directory of the American Congress, 1774-1971 (Washington: United States Government Printing Office, 1971), p. 1159.

*All photographs in this article are from the files of the State Historical Department, Historical Museum and Archives Division. 


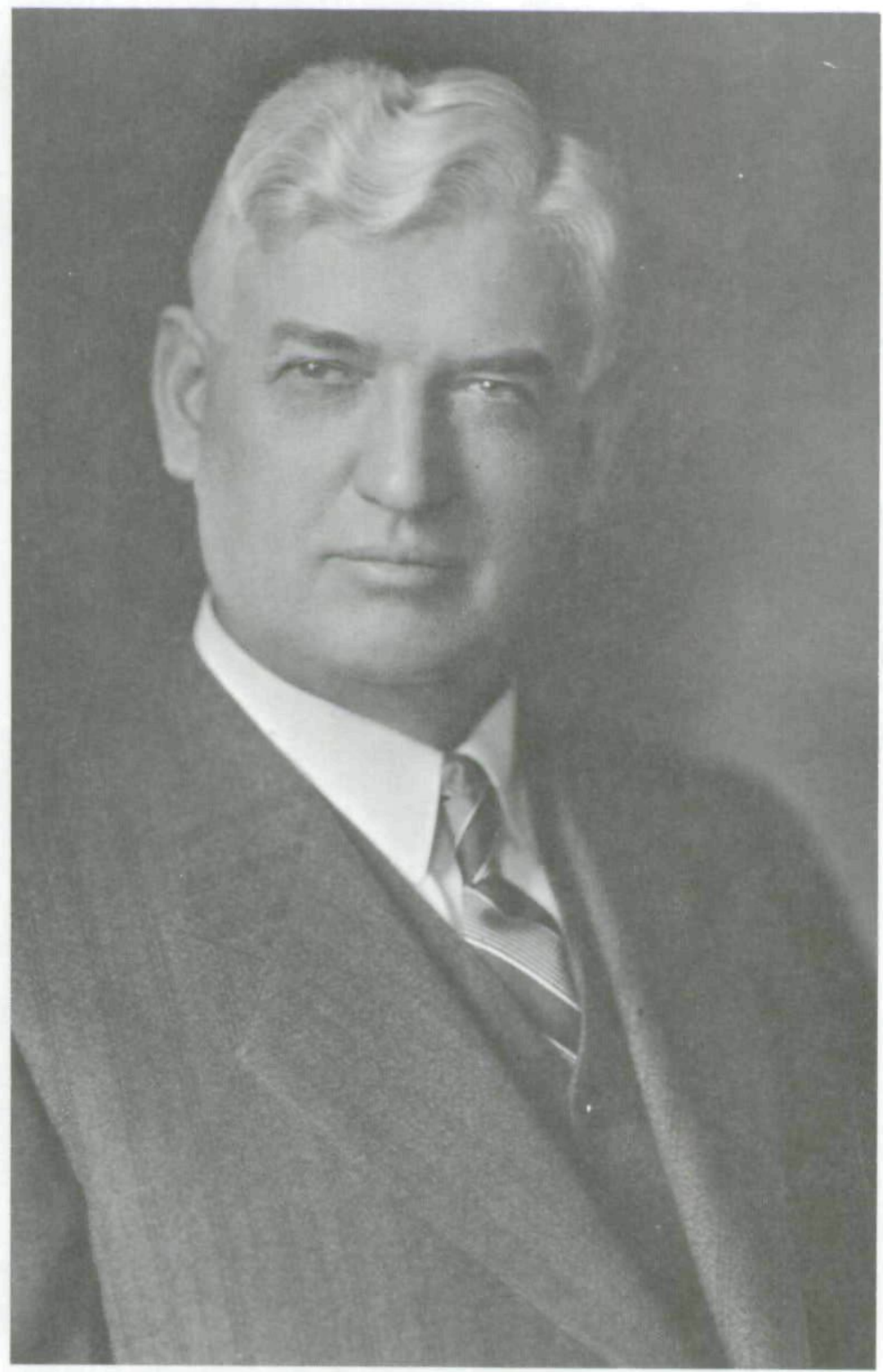

LesterJ. Dickinson 
Committee on Military Affairs, he was one of the principal figures in the acrimonious House debates over whether the national government should lease or sell its power facilities in the Tennessee Valley. ${ }^{2}$ Shortly after retiring from Congress in 1925 , Hull was appointed Commissioner General of Immigration by President Coolidge. ${ }^{3}$ In that capacity he was to devote his attention primarily to the enforcement of the Immigration (National Origins) Act of $1924 .{ }^{4}$

First elected to the House in 1918, Dickinson five years later was assigned to the powerful Committee on Appropriations. ${ }^{5}$ As Chairman of the Appropriations Subcommittee on the Department of Agriculture, 1927-1930, he was a staunch advocate of expanding the existing federal farm programs. ${ }^{\circ}$ In 1930 Dickinson was promoted to the United States Senate. ${ }^{7}$ Possessing considerable oratorical ability, he attracted nationwide attention as keynote speaker at the 1932 Republican National Convention. ${ }^{8}$

${ }^{2}$ United States Congress, Congressional Record, Sixty-Eighth Congress, First Session (Washington: United States Government Printing Office, 1924), LXV. $813-815,1228-1230,2189,2221,3556-3595,3631-3362,3704-3731,3816-3855$, 3901-3928; Sixty-Eighth Congress, Second Session, LXVI, 2294-2295, 2536-2549, 3654-3655; Preston J. Hubbard, Origins of the TVA; The Muscle Shoals Controversy, 1920-1932 (Nashville: Vanderbilt University Press, 1961), pp. 109-125.

'Hull's nomination as Commissioner General of Immigration was submitted to the Senate on December 17, 1925 and confirmed by that body four days later. Congressional Record, LXVII, 999, 1258.

${ }^{4}$ Hull served as Commissioner General until 1933. Succinct accounts of his activities may be found in Annual Reports of the Commissioner General of Immigration. 1925-1933 (Washington: United States Government Printing Office, 1925-1933).

${ }^{5}$ United States Congress, Congressional Directory, Sixty-Ninth Congress, First Session (Washington: United States Government Printing Office, January 1924), p. 190.

${ }^{6}$ Congressional Record, LXIX, 789, 3827, 3786-3821, 3864-3903, 3973-4006, 4023-4049, 7096, 7926, 8328, 8330-8338, 8519, 8581, 8890; LXX, 650, 687-707, $839-849,888-896,2706,3172,3240-3242,3414,3419,3489,4156$; LXXII, 609. $632,634,674-695,762-769,811-823,963-984,1008-1020,7538,9168,9252-9254$, 9258, 9326, 9403, 9667; LXXIV, 868-899, 900-906, 1064, 1066-1070, 1136-1146, $1147-1167,4047,5335-5338,5577,5585,5684,5876$.

${ }^{7}$ Defeating his Democratic opponent, Daniel F. Steck, by a margin of 307, 617-235, 245, Dickinson in 1930 carried eighty-four of Iowa's one hundred counties. State of lowa Official Register. 1931-1932 (Des Moines: Robert Henderson, State Printer, 1932), pp. 438-439.

'Official Report of the Proceedings of the Republican National Convention. 1932 (New York: The Tenney Press, 1932), pp. 19-36; Post, Washington, D.C.. June 15, 1932, pp. 1, 3; Times. New York, N.Y., June 15, 1932, pp. 1, 10. 
Kopp had served his political apprenticeship as Chairman of the Public Utilities Committee in the Iowa House of Representatives. ${ }^{9}$ In April 1921 he was sworn in to the first of six terms in Congress. ${ }^{10}$ During his House career Kopp chaired the following standing committees: Expenditures in the Navy Department, 1923-1925; Labor, 1925-1930; and Pensions, 1931. ${ }^{11}$

A veteran of both branches of the Iowa Legislature, Dowell for many years had been Chairman of the Judiciary Committee in the State Senate. ${ }^{12}$ Altogether he was to spend twentythree years in Congress. ${ }^{13} \mathrm{Be}$ tween 1923 and 1931, Dowell was Chairman of the Committee on Roads. ${ }^{14}$ Conscious of the rapid growth of the automobile industry throughout the years of his chairmanship, he was perhaps Congress' most

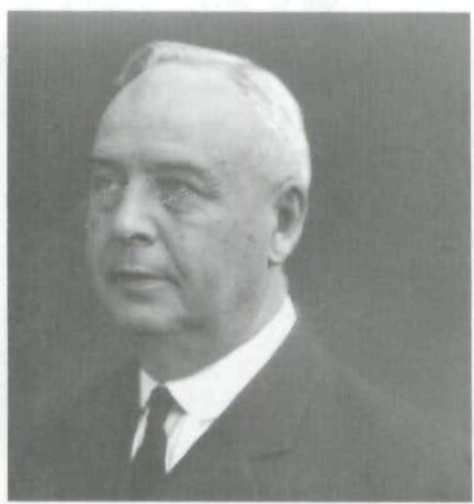

Cassius C. Dowell vociferous spokesman of increased federal aid for highway construction. ${ }^{15}$

Three other Iowa congressmen in April 1921 were Representatives Horace M. Towner of Corning, James W. Good of Cedar Rapids, and William R. Green of Council Bluffs. Collectively Towner, Good, and Green were to spend a total of one hundred years in public service, and during the nineteen twenties were acknowledged as major figures in American government.

After two decades as Judge of Iowa's Third Judicial Circuit,

'State of Iowa, Official Register, 1915-1916, p. 170.

${ }^{10}$ Biographical Directory, of American Congress, p. 1248.

"Congressional Directory. January 1925, p. 204; November 1930, p. 197; January 1931 , p. 199.

${ }^{12}$ State of lowa, Official Register, 1909-1910, p. 160.

${ }^{13}$ Biographical Directory of American Congress, pp. 877-878.

${ }^{14}$ Congressional Directory, January 1931, p. 200.

${ }^{15}$ Congressional Record, LXV, 722, 9390, 10710, 10712-10722, 11113; LXVI, 3249, 3279, 3316, 3531, 3748; LXVII, 4261, 4324, 7459, 7598-7614, 76167637, 11300, 11350, 11379, 11415, 12882, 13092; LXXII, 9, 726, 2061-2084. 2654, 6087-6088, 6345, 6396, 6782; Frederick L. Paxson, "The Highway Movement, 1916-1935," American Historical Review, January 1946, pp. 236-253. 


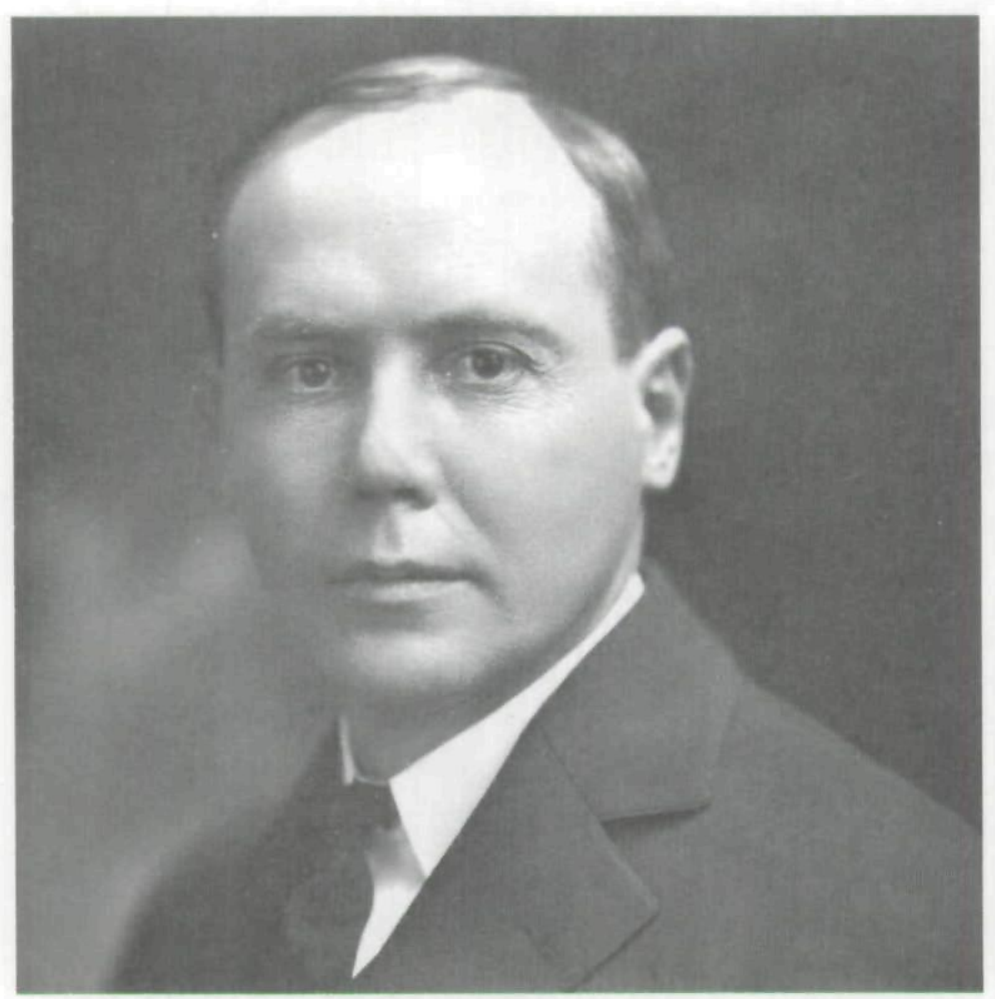

William F. Kopp

Towner had first been elected to Congress in $1910 .{ }^{16}$ In 1921 he occupied the following posts: Chairman of the House Republican Caucus; Chairman of the Committee on Insular Affairs; and ranking Republican member of the Committee on Education. ${ }^{17}$ Towner's foremost legislative contribution was the Maternity and Infancy Welfare (Sheppard-Towner) Act of $1922 .{ }^{18}$ One of the nation's most respected authorities on America's overseas possessions, he resigned from the House in 1923 to accept President

${ }^{10}$ Biographical Directory of American Congress, p. 1825.

${ }^{17}$ Congressional Directory. May 1921, pp. 198, 200.

${ }^{18}$ House of Representatives, Report on the bill (S. 1039) for the public protection of maternity and infancy and providing a method of cooperation between the Government of the United States and the several States. November 14, 1921; Congressional Record, LXII, 6198, 8002-8004; United States Government. The Statutes at Large of the United States of America, 1921-1923 (Washington, 1923), XLII, 224-226. 


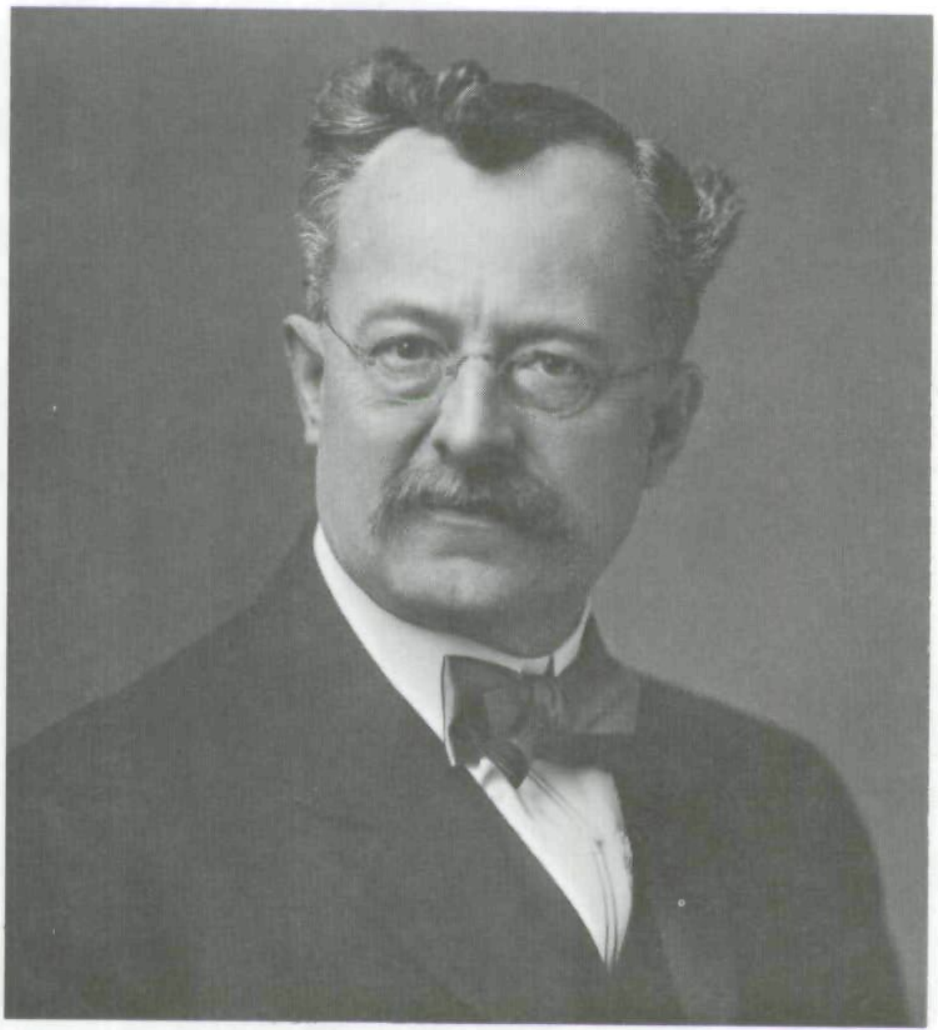

Horace M. Towner

Harding's appointment as Governor of Puerto Rico. ${ }^{19}$

Good in 1921 was beginning his second term as Chairman of the House Committee on Appropriations. ${ }^{20}$ Soon after the Sixtyseventh Congress assembled he was also designated Chairman of the Select Committee on the Budget. ${ }^{21}$ Good's most noteworthy achievement as a member of Congress was the Budget and Accounting Act of 1921, a measure which established both the

${ }^{19}$ Towner's nomination as governor was received by the Senate on March 1 , 1933 and confirmed the following day. Congressional Record, LXIV, 5007, 5130. He served as Puerto Rico's Chief Executive until 1929. Official accounts of his administration may be found in Annual Reports of the Governor of Porto Rico. 1923-1929(Washington: United States Government Printing Office, 1923-1929).

${ }^{20}$ Congressional Directory, May 1921, p. 196.

${ }^{21}$ Ibid., p. 207. 


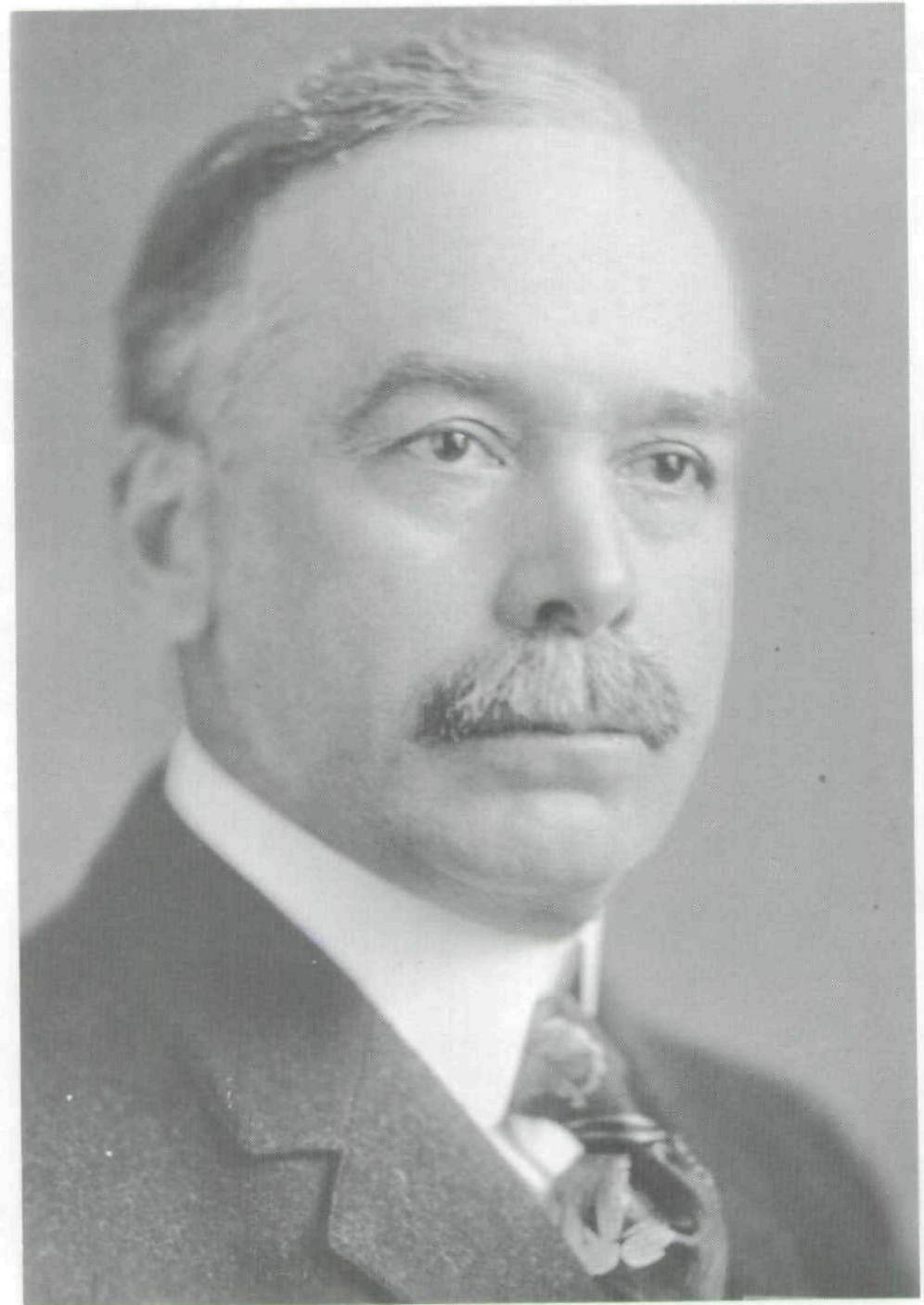

\section{James W. Good}

Bureau of the Budget and the General Accounting Office. ${ }^{22} \mathrm{He}$ resigned from the House in June 1921 and resumed the private

${ }^{22}$ Report on the hill (H.R. 30) to provide a national budget system and an independent audit of Government accounts, and for other purposes. April 25, 1921; 
practice of law. ${ }^{23}$ In 1929 he was appointed Secretary of War by President Hoover, thus becoming the second Iowan ever to occupy that Cabinet post. ${ }^{24}$

Prior to entering the House in 1911, Green had completed seventeen years as Judge of Iowa's Fifteenth Judicial District. ${ }^{25}$ An expert on federal fiscal policy and foreign trade, he was Chairman of the prestigious Committee on Ways and Means, 1923$1928 .{ }^{26}$ Green also presided over the Joint Committee on Internal Revenue between 1926 and $1928 .{ }^{27} \mathrm{He}$ introduced and guided to passage the World War Adjusted Compensation (Veteran's Bonus) Act of $1924 .{ }^{28}$ Green also authored the Revenue Acts of 1924, 1926, and 1928, three of the most comprehensive tax bills ever approved by Congress. ${ }^{29}$ In 1928 he was appointed by President Coolidge to the United States Court of Claims, on which tribunal he served until $1942 .{ }^{30}$

Congressional Record, LXI, 974, 980-999, 1074-1093, 1768, 1851-1859, 1932. 1940. 2500; Statutes at Large, XLII, 20-27; Fritz M. Marx, "The Bureau of the Budget: Its Evolution and Present Role," American Political Science Review, August 1945, pp. 653-684; William F. Willoughby, The National Budget System (Baltimore: The Johns Hopkins Press, 1927), pp. 26-33.

${ }^{23}$ Biographical Directory of American Congress, p. 1013.

${ }^{24}$ Geoge W. McCrary of Keokuk had served as Secretary of War between 1877 and 1879. Robert Sobel (ed.), Biographical Directory of the United States Executive Branch, 1774-1971 (Westport, Connecticut: Greenport Publishing Company, 1971), pp. 132-133, 217-218.

${ }^{25}$ Biographical Directory of American Congress, pp. 1029-1030.

${ }^{20}$ Congressional Directory, January 1928, p. 223.

${ }^{27}$ Ibid., p. 248.

${ }^{28}$ Report on the bill (H.R. 7959$)$ to provide adjusted compensation for veterans of the World War, and for other purposes, March 17, 1924; Congressional Record. LXV, 4308, 4395, 4436, 5531-5547, 7114-7115, 7722-7726, 7734, 7773, 7901, 8660, 8808-8814, 8819, 8825, 8844, 8869, 10914; Statutes at Large, XLIII, 121-132; William P. Dilligham, Federal Aid to Veterans, 1917-1941 (Gainesville: University of Florida, 1952), pp. 145-156; Post, Washington, D.C., March 19, 1924, pp. 1, 3; May 19, 1924, pp. 1, 2.

${ }^{20}$ Congressional Record, LXV, 2253, 2281, 2427-2473, 2486-2531, 25662635, 2666-2726, 2775-2800, 2841-2867, 2898-2926, 2948-2972, 2974, 2994-3019, $3031,3100-3122,3170-3199,3257-3290,3330-3382,8384,9463,9528-9551$, 10341; LXVII, 395, 510-525, 539-567, 642-679, 692-725, 731-757, 771-799, 879$899,937-966,1005-1037,1108-1165,1673,2230,4401-4454,4534,4592,5191$; LXIX, 18, 143, 223, 402-407, 414, 449-452, 599-616, 625-650, 694-718, 9483, 9990, 10131-10138, 10256, 10434, 10752; Statutes at Large, XLIII, 253-355; XLIV, 9-131; XLV, 791-883; R. G. Blakey, "Revenue Act of 1928," American Economic Review, September 1928, pp. 428-448; Randolph E. Paul, Taxation in the United States (Boston: Little, Brown and Company, 1954), pp. 131-141.

${ }^{30}$ Department of Justice, Register of the Department of Justice and the 
The three most influencial Iowans serving in Congress in April 1921 were Representative Gilbert N. Haugen of Northwood and Senators William S. Kenyon of Fort Dodge and Albert B. Cummins of Des Moines. Haugen, Kenyon, and Cummins certainly rank as three of the most distinguished public figures from Iowa over the past century.

Prior to entering Congress in 1899, Haugen had completed six years as a member of the Iowa House of Representatives. ${ }^{31}$ Elected to an unprecedented seventeen terms, he was to establish a record among Iowans for continuous longevity. ${ }^{32}$ Haugen was Chairman of the Committee on Agriculture, 1919-1931. ${ }^{33}$ Generally regarded as the most avid congressional proponent of legislation to alleviate the financial distress of the nation's farmers, he introduced a series of farm relief proposals popularly known as the McNary-Haugen bills. ${ }^{34}$ Although Congress twice approved versions of the McNary-Haugen bill, these measures were vetoed by President Collidge. ${ }^{35}$ Haugen did, however, author such landmark farm legislation as the Cooperative Marketing Act of $1926^{36}$

Courts of the United States, 1942 (Washington: United States Government Printing Office, 1942), p. 38.

${ }^{3}$ Biographical Directory of American Congress, p. 1087.

${ }^{32}$ The record among lowans for continuous service in the United States Senate was established by William B. Allison of Dubuque. Allison's tenure lasted thirty-five years and five months.

${ }^{33}$ Congressional Directory, January 1931, p. 192.

${ }^{34}$ John D. Black, "The McNary-Haugen Movement," American Economic Review, September 1928, pp. 405-427; “'The McNary-Haugen Agricultural Bill," Congressional Digest. May 1924, pp. 263-279; Theodore Saloutos and John D. Hicks, Agricultural Discontent in the Middle West, 1900-1939 (Madison: University of Wisconsin Press, 1951), pp. 372-403; James H. Shideler, Farm Crisis. 1919-1923 (Berkeley: University of California Press, 1957), pp. 267-279; Henry A. Wallace, "Stabilization of Farm Prices and the McNary-Haugen Bill," Annals of the American Academy of Political and Social Science, March 1929, pp. 402-405.

${ }^{35}$ Coolidge first vetoed the McNary-Haugen bill on February 27, 1927, and Congress thereupon refrained from attempting to override the veto. Coolidge vetoed a revised version of the bill on May 23,1928. This veto was sustained by the Senate by a vote of 50-31 on May 25, 1928. Congressional Record, LXVIII, 3518, 4099, 4771-4778; LXIX, 6283, 7771-7772, 9524-9527, 9879-9880; United States Senate, Presidential Vetoes, 1789-1968 (Washington: United States Government Printing Office, 1969;, pp. 95-96.

${ }^{36}$ Report on the bill (H.R. 7893) to create a division of cooperative marketing in the Department of Agriculture; to provide for the acquisition and dissemination of information pertaining to cooperation; to promote the knowledge of cooperative principles and practices; to provide for calling advisers to counsel with the Secretary of Agriculture on cooperative activities; to authorize cooperative asso- 
and the Federal Farm Board Act of $1929 .{ }^{37}$ At the time of his retirement to private life in March 1933 Haugen was the senior member of Congress. ${ }^{38}$

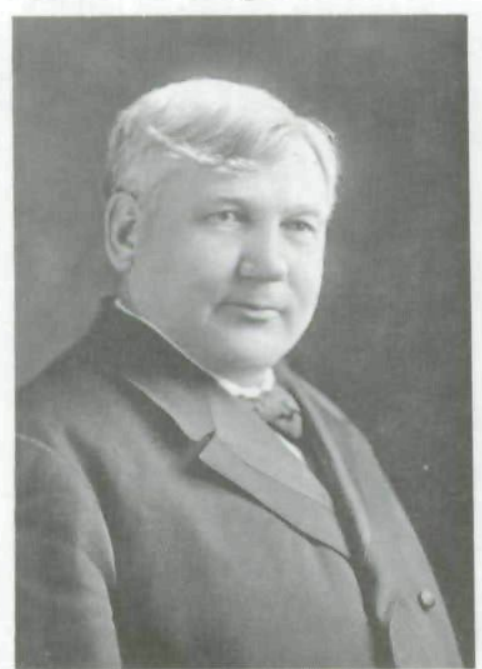

G. N. Haugen

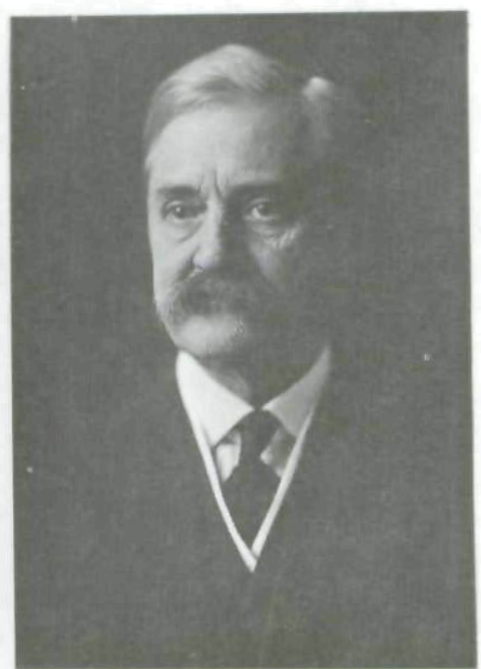

A. B. Cummings

Serving his third term in the Senate, Kenyon in 1921 was Chairman of the Committee on Education and Labor. ${ }^{39} \mathrm{He}$ was one of the public figures most prominently identified with the prohibition movement, having co-authored both the Interstate Liquor Control (Webb-Kenyon) Act of 1913 and the Eighteenth

ciations to acquire, interpret, and disseminate crop and market information. and for other purposes, January 18, 1926; Congressional Record. LXVII, 2338, 2718 2735, 2764-2783, 12453-12456, 12558, 12855, 13092; Statutes at Large, XLIV, 802-803; "Congress and Cooperative Marketing," Congressional Digest. October 1925, pp. 255-286.

${ }^{37}$ Report on the bill (H.R. I) to establish a Federal Farm Board to promote the effective merchandising of agricultural commodities in interstate and foreign commerce, and to place agriculture on a basis of economic equality with other industries. April 17. 1929; Congressional Record. LXXXI, 49. 75, 124-148, 157. $180,188,193-243,280-323,326,381-416,418-420,451-484,501,541,576-584$, 586, 1455, 2517, 2531, 2788, 2887-2894, 2935, 2977-2978; Statutes at Large, XLVI, 11-19.

"An interesting biographical sketch of Haugen's career is Earle D. Ross, "Gilbert Nelson Haugen," Dictionary of American Biography (22 vols; New York: Charles Scribner's Sons, 1928-1958), XXI, 384-385.

${ }^{39}$ A succinct biographical account of Kenyon's career is Earle D. Ross, "William Squire Kenyon," Dictionary of American Biography, XXI, 455-456. 


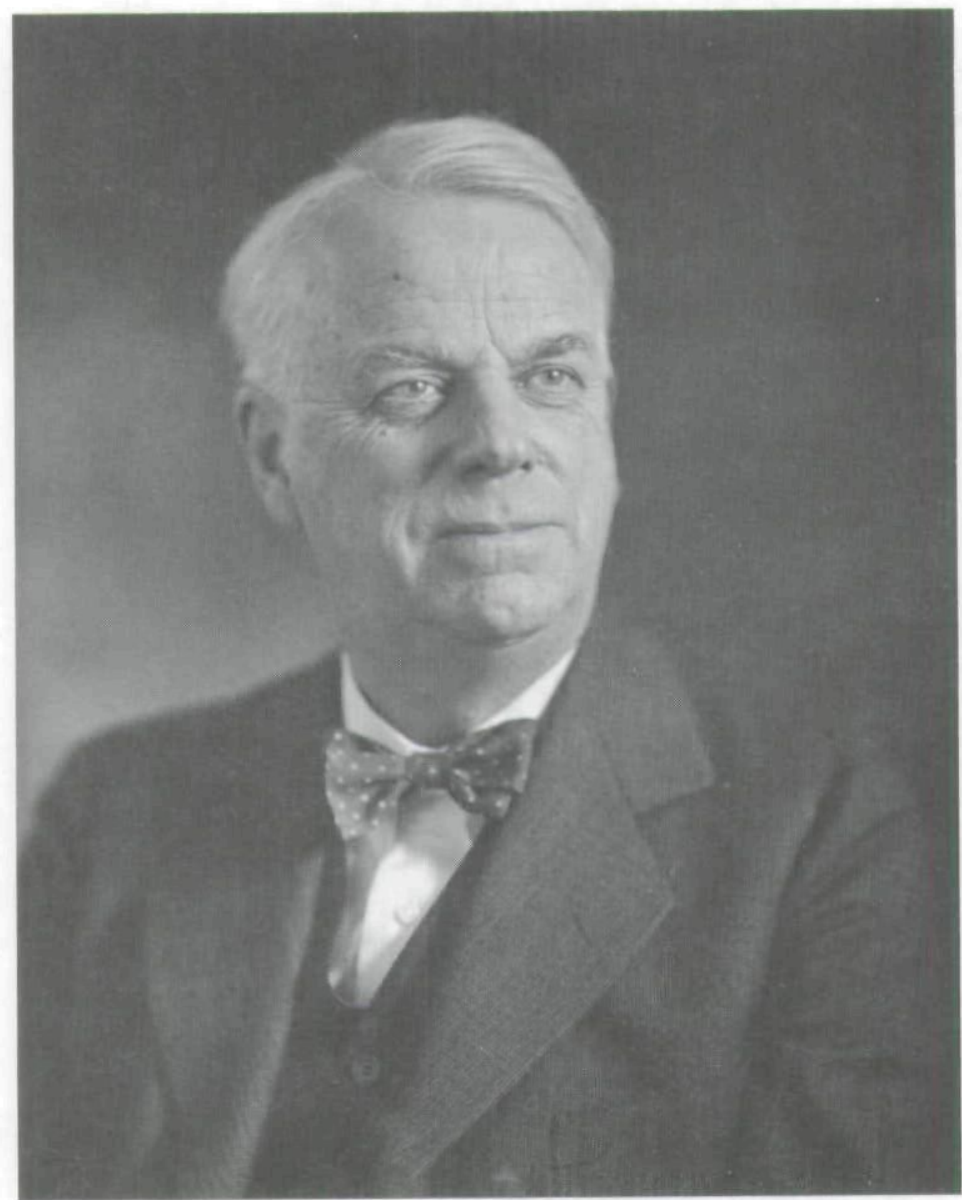

William S. Kenyon

(Prohibition) Amendment to the Constitution. ${ }^{40}$ In February 1922 President Harding appointed Kenyon a Judge of the United States Eighth Circuit Court of Appeals. ${ }^{41}$ Preferring to remain as a federal judge, he declined President Coolidge's offer to become

${ }^{40}$ The Webb-Kenyon bill had been enacted into law on March 1, 1913, after both the House and Senate had overridden President William Howard Taft's veto. The Eighteenth Amendment had been approved by Congress on December 18, 1917 and ratified by the Iowa Legislature on January 15, 1919.

4iThe Eighth Circuit included the States of Arkansas, Missouri, Iowa, Minnesota, North Dakota, South Dakota, Nebraska, Kansas, Oklahoma, Wyoming, 
Secretary of the Navy in $1924 .{ }^{42}$ Two years later Kenyon was to issue the historic judicial ruling which invalidated the Teapot Dome oil lease. ${ }^{43} \mathrm{He}$ also was to serve on the National Commission on Law Observance and Enforcement, a panel created by President Hoover to study the effectiveness of national prohibition. ${ }^{44}$

One of the dominant political personalities in Iowa's history, Cummins was in his third term as governor at the time of his election to the Senate in $1908 .{ }^{45}$ Chairman of the Committee on Interstate Commerce, 1919-1923, he co-authored both the Transportation (Esch-Cummins) Act of $1920^{46}$ and the Coal Distribution and Control (Cummins-Winslow) Act of 1922. ${ }^{47}$ A member of the Committee on the Judiciary throughout his entire Senate career and Chairman of that organ between 1925 and 1926, Cummins was primarily responsible for a 1925 statute reforming the

Colorado, and New Mexico. Register of the Department of Justice and Courts of the United States, 1922, p.44.

${ }^{42}$ The text of the letter in which Kenyon informed Coolidge of his decision not to join the Cabinet may be found in the Washington Post. March 14, 1924, p. 1.

${ }^{43}$ "United States vs. Mammouth Oil Company," Federal Reporter, Second Series (St. Paul: West Publishing Company, 1927), XIV, 705-733; Burl Noggle, Teapot Dome: Oil and Politics in the 1920's (Baton Rouge: Louisiana State University Press, 1962), pp. 182-184; M. R. Werner and John Starr, Teapot Dome (New York:The Viking Press, 1959), pp. 206-208; Times, New York, N.Y., September 29, 1926, pp. 1, 14.

${ }^{44}$ National Commission on Law Observance and Enforcement, Report on the Enforcement of the Prohibition Laws of the United States (5 vols.; Washington: United States Government Printing Office, 1931).

${ }^{45}$ A scholarly account of Cummins' years in public life is Ralph M. Sayre, "Albert Baird Cummins and the Progressive Movement in Iowa," Unpublished Ph.D. Dissertation, Columbia University, 1958.

${ }^{46}$ United States Senate, Conference Report on the bill (H.R. I0453) to provide for the termination of Federal control of railroads and systems of transportation: to provide for the settlement of disputes between carriers and their employees: to further amend an act entitled "An act to regulate commerce, " approved February 4, 1887, and for other purposes, February 18, 1920; Congressional Record, LIX, 323, 884-912, 950-952, 3043, 3326-3350, 3435, 3457, 3484. 3709; Statutes at Large. XLI, 456-499.

${ }^{47}$ Conference Report on the bill (H.R. 12472) to declare a national emergency to exist in the production, transportation, and distribution of coal and other fuel. granting additional powers to the Interstate Commerce Commission, providing for the appointment of a Federal Fuel Distributor, providing for the declaration of car-service priorities during the present emergency, and to prevent the sale of fuel at unjust and unreasonably high prices. September 14, 1922; Congressional Record. LXII, 12070, 12081, 12151, 12170, 12173, 12209, 12223-12235, 12568. 12745-12751, 12852, 12884, 13145, 13182; Statutes at Large. XLII, 1025-1028. 
rule of judicial appeal to the United States Supreme Court. ${ }^{48} \mathrm{He}$ was also President pro tempore of the Senate from 1919 to 1925, during the latter nineteen months of which he assumed the functions normally reserved for the Vice-President. ${ }^{49}$

The ten Iowans chosen to serve in the Sixty-seventh Congress performed with notable distinction. Chairing a number of standing committees and deeply involved in the shaping of major legislation, these representatives and senators compiled admirable records of public service during the Harding-Coolidge-Hoover era. Moreover, their efforts were not confined to service in Congress, but in several cases included important positions in the executive and judicial branches of the government. Indeed the ten aforementioned men - in 1921 - probably constituted the most influential delegation from any single state; and they rank among the most outstanding such group ever to represent the people of Iowa on Capitol Hill.

${ }^{45}$ Report on the bill (S. 2060) to amend the Judicial Code further to define the jurisdiction of the circuits courts of appeals and of the Supreme Court. and for other purposes. April 8, 1924; Congressional Record. LXV, 1074, 5831-5832; LXVI, 2750-2758, 2916-2926, 2928-2929, 3005, 3060, 3091, 3276, 3748; Statutes at Large, XLIII, 936-942.

${ }^{4}$ Between the death of President Harding on August 2, 1923 and the inaugural ceremonies on March 4, 1925 Cummins was the actual presiding officer of the Senate, thus exercising the responsibilities which ordinarily would have been performed by the Vice-President. 
Copyright of Annals of Iowa is the property of State of Iowa, by \& through the State Historical Society of Iowa and its content may not be copied or emailed to multiple sites or posted to a listserv without the copyright holder's express written permission. However, users may print, download, or email articles for individual use. 